Київ, 2009. URL: http://ru.osvita.ua/legislation/Vishya_osvita/4310/ (дата звернення: 27.10.2020).

4. Про затвердження Концепції національно-патріотичного виховання дітей і молоді, Заходів щодо реалізації Концепції національнопатріотичного виховання дітей і молоді та методичних рекомендацій щодо національно-патріотичного виховання у загальноосвітніх навчальних закладах. Київ, 2015. URL: https://zakon.rada.gov.ua/ rada/show/v0641729-15\#Техt (дата звернення: 27.10.2020).

5. Солошенко О. Використання методики ресурсно-орієнтованого навчання при викладанні дисциплін гуманітарного циклу: теоретичний аспект. Новий Колегіум. 2018. № 3. С. 62-67.

DOI https://doi.org/10.30525/978-9934-588-91-4-13

\title{
«ЧЕРНИГОВСКИЙ АДРЕС» 1879 РОКУ \\ ЯК УНІКАЛЬНЕ ДЖЕРЕЛО 3 ІСТОРІЇ ПОЛІТИЧНОӤ ДІЯЛЬНОСТІ І. І. ПЕТРУНКЕВИЧА В УКРАЇНІ (70 РР. ХІХ СТ.)
}

\author{
Котельницький Н. А. \\ кандидат історичних наук, \\ член-кореспондент \\ Центру украӥнських досліджень Інституту Європи РАН \\ м. Чернігів, Україна
}

Життя та широкомасштабна діяльність в Україні засновника, «патріарха» та безсумнівного лідера земського ліберального руху у Російській імперії - Івана Ілліча Петрункевича (1843-1928), були позначені дуже яскравими політичними подіями, які отримали великий суспільний резонанс у державі у силу свого «одіозного» характеру. Без усіляких перебільшень, до згаданих подій можна віднести і колосальний політичний скандал у Чернігівському губернському земському зібранні, який виник у січні 1879 р. навколо підготовленої спеціальною комісією губернського земства офіційної відповіді російському імператору Олександру II та Уряду, які звернулись за допомогою до суспільства з закликом допомогти у боротьбі з революційним терором у країні. Історія підготовки, подання та політичного результату розгляду офіційної земської відповіді, що отримала назву - «Адрес Черниговского земства» достатньо відомі в історичній науці, тому вважаємо можливим не акцентувати на цьому увагу [1, p. 155-165].

Однак, оскільки текст принципово важливого документу, по суті, так і не був офіційно опублікований у Російській імперії згідно наказу 
Олександра II, повний текст унікальної пам'ятки, першоджерела української політичної думки другої половини ХІХ ст., став дорогоцінним надбанням опозиційних кіл еміграції, але не громадськості імперії Романових. Як відомо, текст «Черниговского адреса» був офіційно заборонений російським самодержавством і став частиною архіву таємної політичної поліції. У лютому 1879 р., у столиці українських земель Австро-Угорської імперії - Львові, І.Петрункевич опублікував видатну брошуру - «Ближайшие задачи земства», у якій оприлюднив справжній текст офіційної відповіді владним колам, який не вдалося внести до документу, розробленому і затвердженому спеціальною комісією губернського земства [2, с. 89, 93-95]. Відтак, по великому рахунку, суспільство країни не мало у своєму розпорядженні ні аутентичного варіанту «Черниговского адреса», ні його відредагованої версії.

Вміло використовуючи вкрай короткотривалий період демократизації громадського житті у Російській імперії 1880-1881 рр., представники ліберальної опозиції держави підготували до друку спеціальну працю для відомого журналу «Русская мысль», з метою публічного оприлюднення усіх знакових відповідей земських інституцій на звернення імператора та Уряду, серед яких «Адрес Черниговского земства» вирізнявся своєю радикальністю, не дивлячись на політичне редагування. Праця, яку планувалось опублікувати у серпні-вересні 1882 р., була заборонена до друку цензурою і не вийшла на сторінках журналу. Оскільки у Російській імперії почалась епоха Контрреформ, робота лібералів була видана під назвою «Мнение земских собраний о текущем положении в России» 1883 року,у німецькому Берліні, зусиллями російської політичної еміграції. Саме у цій брошурі і був вперше офіційно опублікований текст відповіді Чернігівського губернського земства владним колам Російської імперії 3 приводу допомоги у боротьбі з революційним рухом. Зважаючи на те, що зміст відповіді ніколи не був предметом окремого дослідження в історіографії, лаконічно проаналізуємо контент видатного документу.

Автори «адресу», доповідачем якого був І.Петрункевич, відразу наголосили на тому, що будь-які репресивні або каральні заходи верховної влади безсилі зупинити поширення та велику популяризацію філософських ідей революційного народництва у Російській імперії. Якщо навіть смертна кара не зупиняє терористів, значить є глибинні причини, що породжують ці ексцеси. У документі відзначалося, що будь-яка ідеологія зароджується, проходить етапи становлення, поширення, найвищого апогею та загибелі тільки за умов, якщо у суспільстві $\epsilon$ сприятливий грунт для подібних явищ. Укладачі документу сміливо вказували на те, що у Російській імперії наявні усі передумови для поступу відповідних філософсько-політичних ідей. Головними причинами колосального поширення радикалізму у країні були названі державна політика у сфері народної просвіти, повна відсутність основ 
демократичного суспільства - свободи слова і друку, яскрава формалізація принципів верховенства права [3, с. 92-93].

У документі було зазначено, що станова,»кастова» політика верховної влади у галузі освіти протиставляє тисячі молодих людей, які мають бажання, але не мають можливості навчатися в університетах владі, та взагалі державному організму, не залишаючи їм іншого вибору, як поповнити ряди радикальних опозиційних течій. Боротьба 3 революційними ідеями була б можлива у разі наявності легальних демократичних інструментів - вільної науки, світської просвіти, ліберальних свобод громадянина. Але суспільство таких можливостей не має, у той час як терористи проповідують свої ідеали нелегальними методами. Свободи слова не існує, земські інституції не мають вільних друкованих органів, наука та освіта позбавлені доступу широких верств населення. Результатом цих процесів стає величезна громадянська апатія у суспільстві. Історичний же процес розвитку держави сприяв тому, що ідеали верховенства права, на відміну від західного світу, не стали провідним імперативом прогресу Російської імперії [4, с. 94-97].

У відповіді було зауважено, що хоча період Великих реформ, беззаперечно, принциповим чином зламав негативні тенденції буття країни, але він не зміг революційно реформувати суспільний організм, оскільки імплантовані демократичні перетворення прямо суперечать основам державного ладу та устрою. Проведені трансформації та модернізація не сприяли утвердженню ідеалів законності та верховенства права, адже ганебні архаїчні рудименти рабовласницького, кріпацького ладу - тілесні покарання, адміністративні інтернування так званих «політично неблагонадійних осіб» без жодного вироку суду все ще мають місце у Російській імперії. Численні ж зусилля створених інститутів місцевого самоврядування, їх звернення та клопотання до верховної влади щодо поглиблення та повноцінного завершення реформаційних перетворень у державі, нахабно та показово ігноруються вищою бюрократією країни. Завершуючи, особлива спеціальна комісія сміливо і прямо відмовляла Олександру II та Уряду у будь-якій допомозі у боротьбі з терористами, оскільки Чернігівське губернське земство не мало для цього жодних інструментів [5, с. 97-98].

Контент-аналіз видатного документу засвідчує, що «Черниговский адрес» 1879 р. є унікальним джерелом з історії політичної діяльності керманича земського ліберального руху в Україні - I. Петрункевича. Оскільки текст відповіді Чернігівського губернського земства верховній владі не був офіційно опублікований у Російській імперії, маємо усі підстави стверджувати, що проаналізована нами доповідь спеціальної особливої комісії є видатною пам'яткою та першоджерелом української політичної думки другої половини XIX ст. Текст відповіді комісії земства яскраво свідчить, що навіть редакційна корекція документу не позбавила його радикальності та політичної сміливості. 


\title{
Література:
}

1. Котельницький Н.А. Іван Ілліч Петрункевич (1843-1928): життя та діяльність в Україні. Riga: GlobeEdit, 2019.197 р.

2. Котельницкий Н.А. Иван Ильич Петрункевич: жизнь и деятельность на Черниговщине. Историко - биографический очерк. М.: Летний сад, 2015. 124 с.

3. Доклад Комиссии Черниговского губернского земского собрания 1879 г. Мнения земских собраний о современном положении в России. Берлин, Типография Е. Бока,1883. С. 91-98.

4. Доклад Комиссии Черниговского губернского земского собрания 1879 г. Мнения земских собраний о современном положении в России. Берлин, Типография Е. Бока, 1883. С. 94-97.

5. Доклад Комиссии Черниговского губернского земского собрания 1879 г. Мнения земских собраний о современном положении в России. Берлин, Типография Е. Бока, 1883. С. 97-98.

DOI https://doi.org/10.30525/978-9934-588-91-4-14

\section{КОНЦЕПЦІї СВІТОВОЇ РОЛІ США В ОСТАННІЙ ТРЕТИНІ ХVIII СТ.: ІДЕЙНІ ВИТОКИ АМЕРИКАНСЬКОЇ ЗОВНІШНЬОЇ ПОЛІТИКИ}

\author{
Котляр О. А. \\ студентка магістратури I курсу історичного факультету \\ Київського національного університету імені Тараса Шевченка \\ м. Київ, Украӥна
}

В останній третині XVIII ст. відбулася кристалізація ідей глобального впливу США. Їх творці (у першу чергу, йдеться про батьківзасновників) спроектували концептуальні основи нової держави i збудували ії на особливих уявленнях про майбутню роль Сполучених Штатів у світі. Як писав А. Гамільтон, Америка була «Геркулесом у колисці», адже саме прагнення до величі та віра в особливу місію стали невід'ємною частиною американської свідомості. А. Сміт у 1776 р. так описував трансформації у Новому Світі: «Із власників магазинів, торговців, адвокатів вони стають державними діячами та законодавцями і зайняті у створенні нової форми правління для великої імперії, яка, постане і перетвориться на одну із найбільш могутніх та грізних, що будь-коли існували» [1, p. viii]. Подібні ідеї в Америці на той час ще не були оформлені у вигляді політичних або філософських концепцій, проте ідеологічне підгрунтя Американської революції, у значній мірі, 